\title{
A mentális, idegrendszeri és szerhasználati zavarok okozta betegségteher kezelése: a Megbetegedések elleni küzdelem prioritásainak (Disease Control Priorities) kulcsüzenetei, 3. kiadás - ismertetés
}

\author{
Addressing the burden of mental, neurological and substance use disor- \\ ders: key messages from Disease Control Priorities, 3rd edition - summary
}

Szerzők: Kis Nóra $\square$

Nemzeti Egészségfejlesztési Intézet

Beküldve: 2016.08.31.

\begin{abstract}
Összefoglaló: A mentális és idegrendszeri rendellenességek, valamint a szerhasználat zavarok előfordulása 41\%-kal nőtt 1990 és 2010 között, ami napjainkban a világ betegségterhének egyik meghatározó okává vált. Ez a kijózanító statisztika nem veszi figyelembe a fenti betegségek esetén keletkező jelentős mortalitási többletet, sem a fent említett zavarok által érintett személyek, gondozóik, és a társadalom szintjén jelentkező társadalmi és gazdasági következményeket. A sokféle hatékony beavatkozás, beleértve a gyógyszeres kezelést, a pszichológiai és szociális intervenciókat, a lakossági valamint közösségi szintű beavatkozásokat, megelőzhetővé és kezelhetővé teszik a rendellenességeket. A lakosság szintjén megvalósitható hatékony beavatkozás például, a hozzáférés korlátozása jogszabályi intézkedésekkel az önkárosító eszközökre vonatkozóan, továbbá a rendelkezésre álló alkohol és az arra való kereslet csökkentése. A közösség szintjén megvalósítható bevált gyakorlat például, a szociális és emocionális kompetenciák fejlesztése az iskolákban. Az egyénre irányuló ellátás szintjén pedig a következő beavatkozási típusokat ajánlják: önsegítés, szülői készségek fejlesztése, speciális mentális betegségtípusok esetében hatékony ellátási szolgáltatások (csomagok), a folyamatos ellátás biztosítása és a későbbi, előre tervezett nyomon követés. A szerzők megállapítják, hogy végső soron a cél összetett, költséghatékony, több szintű, egymással párhuzamosan megvalósítható beavatkozások megtervezése és alkalmazása.

Kulcsszavak: mentális betegségteher, szerhasználati zavarok, pszichoszociális fókuszú beavatkozás, mentális fókuszú megelőző tevékenység, mentális ellátás
\end{abstract}

Summary: The prevalence of mental, neurological, and substance use (MNS) disorders increased by $41 \%$ between 1990 and 2010 and became to date one of the fundamental causes of the global disease burden. This sobering statistic does not take into account the substantial excess mortality associated with these disorders or the social and economic consequences of MNS disorders on affected persons, their caregivers, and society. A wide variety of effective interventions, including drugs, psychological treatments, social interventions, as well as population- and community level interventions can prevent and treat MNS disorders. At the population-level platform of service delivery, effective interventions include legislative measures to restrict access to means of selfharm or suicide and to reduce the availability of and demand for alcohol. At the community-level platform, best practices include life-skills training in schools to build social and emotional competencies. At individual level, the following types of interventions are offered: self-management, 
parenting skills development, providing efficient supply services (packages) for specific types of mental illnesses and ensuring continuous care and subsequent pre-planned follow-up.

The authors conclude that ultimately, the goal is to plan and apply complex, cost-effective, multilevel interventions that can be implemented in parallel.

Keywords: burden of mental disease, substance use disorder, psychosocial interventions, mental health-focused preventive intervention, mental care

\section{BEVEZETÉS}

A WHO 1997-es előrejelzése szerint a 2000 utáni évtizedben az egészségügy legsúlyosabb problémái a lelki betegségek, ezen belül is a depresszió és annak következményei lesznek. Az ezredfordulón közel 450 millióra becsülték a mentális betegségben szenvedők számát. Ennyi ember szenved élete során valamilyen, az életminőséget jelentősen rontó lelki betegségben. A munkaképesség-csökkenés leggyakoribb oka a depresszió, ez a megbetegedés ma negyedik a tíz legnagyobb társadalmi terhet jelentő betegség közül, de az előrejelzések szerint 20 éven belül a második helyre fog kerülni a sorban. Az egész világon közel 70 millió ember és környezete szenved alkoholfüggőségben, 10-20 millió ember kísérel meg öngyilkosságot évente, közülük egy millióan közöttük serdülők és fiatalok - halnak meg öngyilkosság miatt. ${ }^{1}$

A cikk abból a tényből indul ki, hogy a Globális betegségteher (Global Burden of Disease 2010 - GBD) c. tanulmány a mentális, idegrendszeri és szerhasználati rendellenességeket a világ betegségterhének jelentős okaként azonosította. 1990 és 2010 között 182 millió főről 258 millióra, vagyis 41\%-kal nőtt a mentális, idegrendszeri és a szerhasználat okozta abszolút fogyatékossággal élők száma. A GBD szakértői a 2010-es adatbázis adatain regressziós módszert végeztek az előfordulások modellezésére országonként, régiónként, életkor és nem alapján. ${ }^{2}$

\section{A MEGBETEGEDÉSEK ELLENI KÜZDELEM PRIORI- TÁSAIBÓL KÖVETKEZŐ MEGÁLLAPÍTÁSOK}

A „Megbetegedések elleni küzdelem prioritásai” (Disease Control Priorities) egy tanulmány, melyet a Világbank először 1993-ban adott ki. Célja, hogy összefoglalja a konkrét egészségügyi rendellenessé- gekből adódó betegségterheket, továbbá, hogy bizonyítsa a beavatkozások relatív hatékonyságát és költséghatékonyságát a döntéshozók számára. ${ }^{3} \mathrm{~A}$ tanulmány szerint 2010-ben az elvesztett egészséges életévek (disability-adjusted life years - DALY) 10,4\%-át, a korai halálozás miatt elvesztett életévek (years of life lost due to premature mortality - YLL) 2,3\%-át és a korlátozottsággal leélt életévek (years lived with disability - YLDs) 28,5\%-át a mentális, idegrendszeri és szerhasználati zavarok (alkohol, drog) tették ki a világon. Ez a kijózanító statisztika azonban nem veszi figyelembe a jelentős mortalitási többletet a fenti betegségekból adódóan vagy a betegség társadalmi és gazdasági következményeit az érintett személyeknél, a gondozóiknál, és a társadalomban. A szerzők szerint a népesség növekedése és öregedése is hozzájárulhat a mentális, idegrendszeri és szerhasználati zavarok következményeként megjelenő korai halálozás vagy korlátozottsággal leélt életévek számának nagymértékű emelkedéshez, de kitérnek arra is, hogy a szerhasználati rendellenességek növekedése annak köszönhető, hogy az idő előrehaladtával nagyobb lett a szerhasználat gyakorisága, ami 2010-ben legnagyobb mértékben a 15-49 éves korosztályban fordult elő. Ebben az életkori csoportban jellemzően a mentális és szerhasználati zavarok képezték a betegségteher kialakulásának legfőbb okát, az idegrendszeri rendellenességek inkább az idősebb korosztálynál voltak megfigyelhetőek. A cikk említést tesz a nemi különbségekről is: a férfiak 48,1\%-ánál, a nők 51,9\%ánál fordulnak elő a mentális és idegrendszeri zavarok, melyeket a férfiaknál jellemzően gyermekkori eredetű zavarok, skizofrénia, Parkinson-kór vagy epilepszia okozhat, míg a nők körében egyéb mentális zavarok az elterjedtek. A rendellenességek okozta betegségterhek általában a magas jövedelmú országokban 1,6-szer magasabbak, mint az alacsony jövedelmú országokban, mert utóbbiakban viszonylag gyakrabban fordulnak elő más egész- 
ségügyi problémák is, mint például különböző fertőzések vagy perinatális betegségek. A szerzők szerint számos társadalmi tényező is befolyásolja a mentális és idegrendszeri, valamint szerhasználati zavarok hatását és kimenetelét, különösen a következők: demográfiai változók (kor, nem, etnikum), szocioökonómiai státusz (alacsony jövedelem, munkanélküliség, alacsony iskolázottság, alacsony társadalmi támogatás), környezeti események (természeti katasztrófák, háború, klímaváltozás, migráció), és társadalmi változások, melyek a jövedelem változását is előidézik (urbanizáció, környezeti degradáció). Az elemzők megállapították azt is, hogy a mentális, idegrendszeri és szerhasználati zavarokkal élők szegénységbe csúsznak a megnövekedett egészségügyi költségeik, a fogyatékosságból adódó csökkent gazdasági produktivitásuk, valamint a betegséggel kapcsolatos stigma (megbélyegzés) és diszkrimináció miatt. A szegénység csökkentésére irányuló beavatkozásoknak a mentális egészségre gyakorolt előnyeit alátámasztó bizonyíték még kétséges, de egyre nő az erre irányuló törekvések száma. A cikk alapvetése és kulcsüzenete, hogy a mentális, idegrendszeri és szerhasználati zavarok megelőzésével és kezelésével járó egyéni és társadalmi szintű előnyök meggyőző bizonyítéka érvként szolgál a prevenciós beavatkozások fontossága mellett. A szerzők megállapítják, hogy nagyobb hangsúlyt kell fektetni a fent említett zavarok speciális kezelésére és megelőzésére, különösen fiatal korban. Fontosnak tartják, hogy ne diszkriminálják a betegségben szenvedőket és a politika is hajlandó legyen foglalkozni velük, például: költséghatékony beavatkozások kidolgozásával, illetve a szükséges kutatások támogatásával a jobb megelőzés és kezelések kifejlesztésének érdekében.

A szerzők a cikkben összefoglalják és ajánlást tesznek a mentális, idegrendszeri és szerhasználati zavarok esetében lehetséges primer prevenciós és intervenciós tevékenységekre, a lakosságra és a közösségre irányuló prevenciós és intervenciós tevékenységekre, továbbá az egyénre irányuló ellátás lehetőségeire.

A fentiek alapján a következő, lakossági szintű beavatkozásokat fogalmazták meg: a lakosság szintjén legjobb gyakorlat közé tartozik az önkárosító eszközökre vonatkozó hozzáférés korlátozása jogszabályi intézkedések segítségével (önkárosítást és öngyil- kosságot elősegítő eszközök hozzáférésének tekintetében), a rendelkezésre álló alkohol és az arra való kereslet csökkentése, a mentális egészség fontosságára figyelmet felhívó kampányok szervezése és a stigmatizáció elleni hatékony intézkedések megalkotása.

A közösségi szinten bevált gyakorlat gyermekeknél, fejlődési és mentális zavarok esetén a szociális és emocionális kompetenciák fejlesztése az iskolákban (az élethez szükséges készségek elsajátítása az oktatásban, amely hozzájárul a szociális és emocionális kompetenciák kiépítéséhez), a szülők támogatása, edukációja a gyermek korai fejlődésével kapcsolatban, valamint a gyermekek életkészségeinek fejlesztése és identitásfejlődésük támogatása. Felnőtt célcsoport esetében a munkahelyen megvalósuló programokat, stresszkezelési tréningeket javasolnak.

A szerzők minden mentális, neurológiai és szerhasználati zavarok esetén hangsúlyozzák a kapuőr funkcióval rendelkező segítők - például, szociális munkások, rendőrök, tanárok - képzését. Az egyénre irányuló ellátás szintjén elsőként az öngondoskodás szerepét emelik ki. Felnőtt célcsoport esetében a zavarok megelőzése érdekében felhívják a figyelmet a fizikai aktivitás szerepére, a relaxációs technikákra, és külön kitérnek az interneten és okos telefonok alkalmazásain keresztül elérhető pszichológiai terápiák hatékonyságára, ami mind gyermekek, mind felnőttek esetében egyaránt ajánlható.

A cikk írói az alapellátás szintjén kiemelik a betegség felismerésének (diagnózis) és az ellátás folyamatos jellegének fontosságát, továbbá a beteg nyomon követését a rendszerben. A szakellátás szintjén a szerzők kitérnek a különböző mentális zavarok gyógyszeres terápiájára és arra is, hogy egyes speciális tünetek esetében (pl. önkárosítási formák, öngyilkosság) hatékony ellátási csomagot javasolnak. Az elemzők a pszichiátriai szakellátás szintjén is hangsúlyozzák a speciális ellátási csomag szerepét, ezen kívül speciális terápiákat ajánlanak, például, elektrosokk-terápiát, vagy kognitív viselkedésterápiát.

A megelőző tevékenységek módszerei közül, hangulat- és szorongásos zavarokra kognitív viselkedésterápiát, míg magatartászavarokra a szülői készségek fejlesztését célzó, valamint szociális és emocionális jóllétet és kompetenciákat fejlesztő tréninget javasolnak. Pszichoszociális intervenciók közül szintén a 
kognitív viselkedést és a személyközi terápiát, skizofrénia esetén a család és a közösségi alapú rehabilitációt és az önsegítő, támogató csoportokat ajánlják. Magatartás- és fejlődési zavarok esetében a szülői készségek fejlesztését célozzák, szorongásos zavarok esetében a kognitív viselkedésterápiát, alkohol és drogfüggőség esetében a pszichoszociális beavatkozások közül a család segítését, az önsegítő csoportokat és a leszokás támogatását tartják célravezetőnek, melyek egyaránt hozzájárulhatnak a rendellenességek megelőzéséhez és kezeléséhez. A szerzők megállapítják, hogy végső soron a cél biztosítani a mentális, idegrendszeri és szerhasználati zavarokkal küzdő emberek hozzáférését a szükséges segítséghez a diszkrimináció és elszegényedés terhe nélkül, ezzel is hozzájárulva az optimális egészségügyi és társadalmi eredmények eléréséhez. Ehhez pedig összetett, költséghatékony, több szintű, egymással párhuzamosan megvalósítható beavatkozásokra van szükség.

\footnotetext{
${ }^{1}$ Kopp, Skrabski 2006: Magyar lelkiállapot az ezredforduló után http://www.tavlatok.hu/86/86kopp skrabski.pdf (Elérve: 2016.11.29.)

${ }^{2}$ Whiteford HA, Degenhardt L. Rehm J. et al. Global Burden of disease attributable to mental and substance use disorders: findings from the Global Burden of Disease Study 2010. Lancet 2013; 382:1575-86. In Patel, Chisholm, Parikh et al. Addressing the burden of mental, neurological, and substance use disorders: key messages from Disease Control Priorities, 3rd edition 2015. Lancet 2016; 387:1672-85.

${ }^{3}$ Jamison DT. Disease Control Priorities, 3rd edition: improving health and reducing poverty. Lancet 2015. In In Patel, Chisholm, Parikh et al. Addressing the burden of mental, neurological, and substance use disorders: key messages from Disease Control Priorities, 3rd edition 2015. Lancet 2016; 387:1672-85.
} 